\title{
Learning from Culturally Relevant Pedagogy and Critical Discourse Analysis: Informing and Successfully Impacting Foreign Language Teaching
}

\author{
Erika Abarca Millán \\ $\mathrm{PhD}$ in Education, University of Pittsburgh \\ Contingencies: A Journal of Global Pedagogy, volume 1, number 1, Spring 2021; \\ https://doi.org/10.33682/eeym-xanb
}

\section{Introduction}

In recent decades, there has been great emphasis and debate on what constitutes culture in the foreign language classroom: how we should teach culture (Kramsch, "Teaching Language along the cultural faultline", "The Symbolic Dimensions of the intercultural"); how culture is represented in foreign language textbooks (Canale; Weninger and Kiss); and how culture is included in classroom practice (Moeller and Osborn; Skopinskaja). This paper aims to redirect the conversation and broaden its scope to focus not only on the target language's culture but also the student's sociocultural contexts. Further, this paper also argues for a critical perspective in addressing culture in the foreign language classroom. I address these issues by drawing from an approach to pedagogy that centers all aspects of learning on students' cultural references (Ladson-Billings, "But That's Just Good Teaching!"; Gay) and a complementary approach to language study that focuses "on the role of discourse in the (re)production and challenge of dominance" (van Dijk, "Principles of Critical Discourse Analysis" 283). Even though these approaches have been widely used and studied, they have not been particularly popular in foreign language teaching (FLT). Therefore, the main purpose of this article is to argue for the relevance of these approaches to foreign language teaching and to present their benefits when 
applied to language learning pedagogies. In the following section, I present a brief overview of Critical Discourse Analysis (CDA) and Culturally Relevant Pedagogy (CRP), including pertinent literature on their application in foreign language classrooms. Then, I present a brief example of how I implemented these approaches in the classroom. I conclude by offering general remarks on these two complementary approaches and their value to foreign language teaching. It is important to mention that even though I refer mostly to foreign language education, the methods and theories discussed here are applicable to language learners more broadly.

\section{Literature Review}

Critical Discourse Analysis and foreign language teaching

\section{Theoretical background}

Critical Discourse Analysis (CDA), also referred to as Critical Discourse Studies (CDS) and sometimes used interchangeably with Critical Linguistics, has its roots in "Rhetoric, Text linguistics, Anthropology, Philosophy, Socio-philosophy, Cognitive Science, Literary Studies and Sociolinguistics, Applied Linguistics and Pragmatics" (Wodak and Meyer, "Critical Discourse Analysis" 1). CDA is a problem-oriented, inter- or multi-disciplinary approach to studying social problems through the systematic analysis of language and texts (Machin and Mayr). CDA primarily seeks to identify and analyze "discursively enacted or legitimated structures and strategies of dominance and resistance in social relationships of class, gender, ethnicity, race, sexual orientation, language, religion, age, nationality or world-region" (van Dijk, "Aims of Critical Discourse Analysis" 18).

Given the wealth of traditions that have influenced it, CDA draws from several disciplinary backgrounds, which, in turn, bring great diversity in terms of methods and foci of investigation. For CDA, language is a form of social practice (Fairclough and Wodak) and 
therefore assigns great importance to the context of language use (Wodak and Meyer). Further, its critical component aims at "producing and conveying critical knowledge that enables human beings to emancipate themselves from forms of domination through self-reflection" (Wodak and Meyer 7). Therefore, CDA goes beyond identifying and understanding, for example, lexico-grammatical and semantic components ${ }^{1}$ in any given text or discourse; it aims at unveiling how specific discursive structures and resources are used to understand social issues and denounce social problems, such as dominance and inequality (van Dijk, "Principles of Critical Discourse Analysis").

In general educational terms, CDA can empower learners by giving them a critical analytical framework to aid reflection on their own language experiences and practices, and those of others, in the institutions and the larger society of which they are part (Clark and Ivanic 217). Concerning critical approaches more specific to language learning, Norton and Toohey posit that when looking at language learning in terms of its relationship to social change, language is conceptualized not solely as a means of expression, but as a social practice that constructs, and is constructed by, "the ways language learners understand themselves, their social surroundings, their histories, and their possibilities for the future" (Norton-Peirce and Toohey 1).

From the point of view of language development, Wallace asserts the importance of reading and analyzing texts critically because it promotes improvement in language proficiency, showing learners the different choices they have available in the language (Wallace, Critical Reading in Language Education). Thus, learners conceive of language as a system of choices. Moreover, as mentioned, CDA conceives language as a social practice that is created in social interactions; in order to understand the discourses in a given language, we need to understand the

\footnotetext{
${ }^{1}$ It is important to mention that CDA is not limited to "verbal" forms of discourse; it has developed theories that pay attention to other semiotic dimensions of communicative events, such as pictures, films, sounds, and gestures (van Dijk, "Aims of Critical Discourse Analysis").
} 
contexts in which they take place, which, in the case of foreign language teaching, lead us to examining the culture, values, and histories of the target language. According to Kern, texts from an L2 culture reflect and constitute that culture; therefore by engaging with those texts, students can understand not only the texts but also the structures they perform (Kern). If teachers give students the tools to analyze and critically read these texts using CDA, they are helping students improve their language proficiency and empowering them in their language-learning process, bringing a critical view to the new cultural worlds encountered in foreign language texts.

Expectations for student interaction with the foreign/second culture and language point to a perspective on language teaching that is directly related to Critical Pedagogy (Freire; Giroux and McLaren; Giroux; McLaren; Luke and Gore). The critical aspect in language learning entails externalizing, naming, and questioning the world, which goes hand in hand with action that resists the psychological and physical violence and material disempowerment that have become the reality for many language learners (Norton-Peirce and Toohey 2).

Following CDA approaches, in order to relate discourse to the society in which it takes place, there needs to be a careful examination of the role of social representations in the minds of social actors (van Dijk, "Principles of Critical Discourse Analysis"). By engaging with FL texts in an active and critical way, students analyze how social actors are represented in these texts and compare/contrast these representations with those of their own cultures.

\section{Review of studies using CDA in foreign language teaching}

In the following paragraphs, I will summarize some of the most pertinent literature found in Spanish and English that has empirically examined the use of CDA in foreign language teaching. It is interesting to note that, though the literature is not extensive, it has definitely 
increased in the past decade. In fact, in the few seminal comprehensive reviews of CDA studies in education (Rogers et al.; Rogers and Schaenen), only one article that addresses FLT is included in the 2005 review, while there are 17 in the 2012 review. Most articles in this last review focus on the use of CDA for analyzing different aspects of foreign language teaching (e.g., classroom interaction, textbooks), rather than as a pedagogical resource.

Though there is research that reports on the benefits of using CDA in teaching languages other than English, there is a clear predominance of works in English as a Foreign Language (EFL). CDA has been used in many aspects of foreign language teaching: to analyze foreign language textbooks (Aljuaythin; Bori and Petanović; Ducar; Setyono; Shardakova and Pavlenko; Xiong, "Essence or Practice?”; Xiong, "Shallow Environmentalism"; Xiong and Yuan; Liu; Xiong and Qian); to analyze interaction in the foreign language classroom (Behnam and Pouriran; Cárdenas and José Francisco; Kim; Sadeghi et al.; Sunardi et al.; Yoshida; Xin et al.); to analyze how certain foreign language programs are being presented in the media (Glas); to analyze student discourse and identity (Bonnah and Donnellan; Gómez Lobatón); and to analyze student and teacher representations in official discourse (Guerrero). This review, however, focuses on empirical studies that have examined implementations of CDA in the foreign language classroom as a pedagogical resource.

The studies included below show research on foreign language teaching using CDA that has focused on four main aspects of the language-learning process that are meant to be developed: 1) language skills, mostly reading comprehension, accuracy, and fluency (Fernández Martínez; Marashi and Chizari; Abbasian and Malaee; Asgharzadeh); 2) critical language awareness (Marsh; Pascual); 3) critical thinking (Dar et al.; Hashemi and Ghanizadeh; Khanshan and Kuhi; Najarzadegan et al.); and, 4) critical intercultural awareness (Hazaea). 
First, certain studies have aimed to teach and implement CDA methods with the purpose of improving reading comprehension and motivation (Abbasian and Malaee; Asgharzadeh). For example, Abbasian and Malaee set out to examine the effects of explicit teaching of CDA techniques on Iranian EFL learners' reading comprehension abilities and attitudes about learning English (Abbasian and Malaee 7). Following Fairclough's three-dimensional model (Fairclough, Discourse and Social Change), the authors randomly assigned 30 undergraduate students (ages 19 to 26) from Bandar Anzali Azad University to an experimental group, where they were taught a critical reading approach. Another 30 students received reading instruction through a more traditional approach and constituted the control group. Both groups read and analyzed the same passages from the British press. Comparing qualitative and quantitative analysis of the pre- and post-CDA instruction responses of the students in the experimental group, the study authors found that students showed a much better awareness and understanding of the writer's biased ideologies after instruction; the students were able to make critical statements about the content of the text, and to identify specific linguistic features of the text and the roles they played in presenting the writer's beliefs and thoughts (12).

Similar results were obtained by Marashi and Chizari when analyzing students' writing after CDA instruction. The authors focused on examining 60 female intermediate EFL students' gains in writing complexity, accuracy, and fluency. Students were randomly separated into two groups: experimental and control. The experimental group received instruction in techniques to analyze texts critically, following general recommendations by Wallace and Kress (Wallace, "Critical Language Awareness"; Kress). To guide their analysis of the texts, students were given questions that focused on identifying the author's role, audience, topic, purpose, and linguistic choices used by the author to construct the meanings in the text. Later, students were presented 
with Fairclough's three-dimensional analysis, which includes the object of analysis (verbal, visual, both); the process by which the object is produced and received by people (writing/speaking/designing and reading/listening/viewing); and the socio-historical conditions in which these processes take place (Fairclough, Discourse and Social Change 73, 199). Findings from this study showed that CDA-based instruction had a positive impact on EFL learners' writing complexity, accuracy, and fluency, and students under this type of instruction were more engaged in the tasks at hand.

Second, some studies have used CDA in the classroom with the goal of raising Critical Language Awareness. Fairclough described the concept of critical language awareness as "conscious attention to properties of language and language use as an element of language education" (Fairclough, Critical Language Awareness 2). According to Clark and Ivanic, Critical Language Awareness allows the student to challenge discourse conventions that disrespect or disempower any given social group (Clark and Ivanic 224), making Critical Language Awareness an essential element of critical pedagogy in language education (Wharton; Morgan). With this idea in mind, Marsh created an exploratory action research project that used CDA-based activities in a Japanese medical university to analyze their effects on Critical Language Awareness levels in students. Results from this study show CDA helped students develop Critical Language Awareness. The author explains, however, that this was not the case for all students, and that a perceived lack of critical skills in some students might be due to "a lack of cultural and linguistic knowledge combined with the cognitive constraints of operating in a foreign language" (Marsh 51).

Similarly, Pascual implemented a series of strategies to develop Critical Language Awareness (Fairclough, Critical Language Awareness) in EFL students' reading abilities 
(Pascual) at an Argentinian university. In conjunction with CDA, Pascual used language analysis tools provided by the Appraisal system (Martin and White), which is part of a larger framework, Systemic Functional Linguistics (Halliday and Matthiessen). In short, the Appraisal system focuses on qualitative, detailed, systemic analysis of evaluation in discourse, making context a fundamental aspect of the analysis, just as in CDA. The students in Pascual's study were presented with the key aspects of CDA and the Appraisal System to analyze a New York Times article on the death of former Argentinian president, Néstor Kirchner. Through this analysis, students were able to understand and find evidence of the abusive discourse used by the media in order to achieve their own agenda (van Dijk, Ideology). Pascual stresses the importance of analyzing the sociohistorical contexts in which texts are created and consumed, and the relevance of a critical position in relation to those contexts, which directly aids students' empowerment.

Third, some studies investigated the impact of CDA instruction in Foreign Language Critical Thinking skills. Development of Critical Thinking skills in intensive language programs has been linked to high levels of success in preparing international students for academic challenges (Węgrzecka-Kowalewski). Students' development of Critical Thinking skills has also been found to be linked to the development of other emotional, motivational, and metacognitive factors (Leung and Kember). Further, the development of Critical Thinking can contribute to the tolerance of ambiguity, the taking of responsibility, and the enhancement of confidence and self-efficacy (Kuiper). Based on these positive outcomes, Hashemi and Ghanizadeh set out to test their hypothesis that CDA instruction could positively influence EFL students' Critical Thinking skills. The authors used an experimental design with 53 participants from a university in Mashhad, Iran. The students were divided into an experimental group and a control group, with the experimental group receiving CDA instruction in the curriculum for a course in reading 
journalistic texts. The experimental and control groups received pre- and post-tests using Watson-Glaser Critical Thinking Appraisal (Watson and Glaser). Findings suggest that the integration of CDA in the curriculum enhanced students' Critical Thinking abilities. More specifically, CDA had the most significant impact on two critical thinking components: 1) interpretation; and, 2) the recognition of unstated assumptions. Given that the first component is an essential part of all models of CDA, the findings are not surprising. The second component, according to Hashemi, seems to be plausible given that CDA enables students to read between the lines and to uncover and challenge ideological assumptions present in texts (Hashemi and Ghanizadeh 43).

Fourth, there were studies that included CDA in the curriculum in order to develop Critical Intercultural Awareness. For example, Hazaea drew from two related concepts: critical language awareness (Wallace, "Critical Language Awareness") and intercultural awareness (Baker; Chen and Starosta; Perales Escudero; Zhang and Steele), operationalizing Critical Intercultural Awareness as "the ability of EFL students to effectively and appropriately decode and encode cultures of self and others as intercultural competitive discourses associated with an intercultural topic in intercultural texts" (Hazaea 20). Hazaea used an interventional project to investigate pre- and post-treatment reflective writings in EFL students' portfolios in their preparatory year at a Saudi university. The teacher-researcher presented students with CDA tools for analyzing intercultural texts and, after that, asked them to read a text and write creatively on the topic: a dinner invitation. These writings became part of the students' portfolios, which were later analyzed. Findings show that students were able to demonstrate a balanced intercultural awareness in relation to the discourse of food diversity. Students also appreciated cultures of, and showed appropriate intercultural knowledge of, the self and others. 
Finally, it is important to mention that there are other studies that, though they do not explicitly use CDA, do provide students with tools that allow them to develop their Critical Thinking skills. This is the case with studies that have looked into the use of Systemic Functional Linguistics and language learning. For example, some studies (Achugar et al.; Schleppegrell et al.; Schleppegrell and Achugar) have used Systemic Functional Linguistics to critically assess explanations in history textbooks as students develop their academic English skills. Other studies have used Systemic Functional Linguistics to teach specific genres or registers in a foreign language (Fernández; Abdel-Malek; Schleppegrell et al.; Fang and Schleppegrell). Nevertheless, Systemic Functional Linguistics is not by itself under the umbrella of CDA, though these approaches have often been used together given that they have similar views on language and are quite complementary. Providing students with the main tools to implement these approaches in their language learning is yet another way in which students can engage critically with texts and discourses.

\section{Culturally relevant pedagogy}

\section{Theoretical background}

Deficit approaches to the cultures and languages of communities of color have been present in the U.S. for many decades. These approaches viewed the languages, literacies, and cultures of students and communities of color as deficiencies that needed to be overcome to favor the dominant languages, literacies, and cultures that were the norm in schools (Paris and Alim 87). During the 1960s and 1970s, court rulings and language policies required schools and practitioners to attend to the cultures and languages of communities of color in the United States.

As a result, researchers and teachers began collaborating to move away from deficit perspectives. 
Paris and Alim state that this body of research created through collaboration (e.g., Moll; Cazden and Legget; Heath; Labov; Smitherman) began the development of asset pedagogies, which through the subsequent decades were enacted and understood in complex ways by both teachers and researchers (e.g., Ladson-Billings, The Dreamkeepers; Valdes; Nieto; Moll and González).

In 1995, Gloria Ladson-Billings wrote a seminal article (Ladson-Billings, “Toward a Theory") in which she moves away from programmatic reforms to create equitable and just educational experiences for all students, and proposes a theory of culturally-focused pedagogy to reform teacher education. In this article, she defines Culturally Relevant Pedagogy (CRP) as “a theoretical model that not only addresses student achievement but also helps students to accept and affirm their cultural identity while developing critical perspectives that challenge inequities that schools (and other institutions) perpetuate" (465).

Given its relevance and impact in the field, and due to space constraints, I've decided to focus on Ladson-Billings' approach to asset pedagogies, but it is important to mention that there are other important terms and concepts that have developed with asset pedagogies including, but not limited to, culturally responsive pedagogy (Gay), culturally compatible pedagogy (Jacob and Jordan), engaged pedagogy (hooks), and linguistically responsive teaching (Lucas et al.; Lucas and Villegas).

Since her 1995 article, Ladson-Billings has continued to develop her framework, but here I share the most general tenets of her theory, which has been influenced by the work of many scholars in the field. Ladson-Billings identified four main components in her theory: social context, the students, the curriculum, and instruction.

- Social context asks teachers to realize that teaching takes place beyond the context of the classroom, and that it takes place in schools and communities. Therefore, teachers should 
understand the inequities that exist beyond their classrooms and they should prepare students to fight these inequities by "being highly competent and critically conscious" (30).

- Concerning the students, Ladson-Billings asks teachers to understand the complexities in their lives, to see the possibilities within them, and to move their teaching practice away from sympathy towards informed empathy, making teachers feel with students rather than for them.

- In relation to the curriculum, teachers are asked to understand it as a cultural and ideological artifact and, as such, to be able to: a) deconstruct it, approaching it critically, and exposing weaknesses, omissions, and myths; b) construct it, building it with the knowledge they themselves and their students bring to the classroom; and, c) reconstruct it, rebuilding the curriculum from what was taken apart and examined ("From the Achievement Gap to the Education Debt" 32).

- When discussing instruction, Ladson-Billings calls on teachers to provide students with knowledge that engages them intellectually and moves them to participate, preparing students for the demands of the society they live in.

Ladson-Billings also discusses three elements that culturally relevant teachers should address in their classrooms: academic achievement, cultural competence, and sociopolitical consciousness. In her conceptualization, academic achievement is not related to the standardized testing or scripted curricula with which it is commonly associated, but to "what students actually know and are able to do as a result of pedagogical interactions with skilled teachers" ("Yes, But How Do We Do It?” 34). In relation to academic achievement, she asserts that teachers should ask themselves what they are teaching and why students should learn about it. She argues that 
one of the most important activities that students should be engaged with in the classroom is the critique of texts and activities, which provides a natural link to CDA. Ladson-Billings states that the reasoning behind the choice of activities in the classroom should be made explicit so that students are aware of how different components are linked, helping them to stay motivated and achieve the main goals of the class.

The cultural competence element refers to helping students recognize and value their own cultural practices and beliefs while they acquire access to a wider culture, with the goal of improving the lives of the students, families, and communities they aim to serve. The last element emphasized by Ladson-Billings is sociopolitical consciousness: teachers need to develop their own consciousness and link, for example, economic disparities, with issues of race, class, and gender. Once they have educated themselves on these issues, they will be able to incorporate these into their teaching and help students understand and critique their own contexts and social positions (Ladson-Billings, “Yes, But How Do We Do It?” 37).

Finally, I think it is important to reiterate that CRP has continued to be developed and “remixed"—using Ladson-Billings' term—over the years. Among these re-conceptualizations, Paris' 2012 article is a major contribution. Paris, while acknowledging that Ladson-Billings laid the groundwork by theorizing CRP, critically reflects on the term culturally relevant. He claims that relevance and responsiveness do not guarantee the educational programs' goal of maintaining heritage ways. He proposes the alternative term culturally sustaining pedagogy, which, in his assertion, better conveys its goal "to perpetuate and foster - to sustain - linguistic, literate, and cultural pluralism as part of the democratic project of schooling" (Paris 93). 


\section{Review of studies using CRP in foreign language teaching}

Even though the literature on CRP and related approaches is extensive and spans most content and geographical areas, it has only been minimally engaged in second or foreign language instruction. Research that intersects these areas has been growing in the last decade, however. In this section, I will briefly present some pertinent articles that discuss culturally relevant pedagogy, or related approaches, and language education (i.e., foreign language education, second language education, English as a Second Language (ESL), English Language Learners (ELL)).

The literature that has examined language education through a CRP lens has focused on different aspects, and here I mention examples of five that, to my knowledge, are the most common: 1) the experience of pre- and in-service language teachers when implementing CRP in their classrooms (Porto; Dost; Nero; Nzai et al.; Blair; Mellom et al.); 2) student identity (Cole et al.); 3) literacy and language development (Habli; McIntosh et al.); 4) classroom participation and motivation (Kissau et al.; Chen and Yang); and 5) technology and online teaching (Hesar et al.; Tan et al.). These are some examples of articles that have explicitly mentioned using CRP in language teaching to affect different aspects of instruction. It is important to note that among these studies there are some that have incorporated and used CRP thoughtfully, weighing the complex sociopolitical implications of its implementation in relation to students' cultures and contexts. Unfortunately, there are others that have reduced the implementation of CRP to a set of fixed strategies that should be replicated, regardless of the context, in order to improve linguistic proficiency. In the following paragraphs, I will present some examples from some of the most important themes mentioned above that, to my judgment, more closely follow CRP and its previously explained tenets. 
The great majority of articles that approach language teaching from a CRP perspective do so to assess and inform pre- or in-service practitioners. Melina Porto asserts the importance of $\mathrm{EFL/ESL}$, and foreign language educators in general, developing awareness, knowledge, and strategies for grappling with the complexity of integrating language and culture into the reality of their classrooms. She describes a series of tasks she uses with teachers that focuses on raising their awareness of what culturally responsive literacy education means. Some of the activities she proposes entail teachers reading short texts that provide a definition for culturally responsive instruction and analyzing these definitions critically (Porto 52). In these activities, teachers are required to reflect on the complexity and the responsibility that being a culturally responsive educator demands. In her article, Porto cautions that developing this awareness is usually destabilizing because it subverts the pre-conceived, fossilized notions about our practices and students that we need to reflect upon and contest. At the same time, this reflection can be a platform "for critical, reflexive and continual self-development, both professionally and personally" (Porto 51).

Shondel Nero also analyzes her work with pre- and in-service teachers (17 graduate students from different institutions in the New York area), but her study included a four-week study abroad seminar in the Dominican Republic. Nero's study is distinct in that she did not work directly with teachers trained in second or foreign language acquisition but rather teachers of students whose first language was not English. The teachers who enrolled in the seminar were in the New York metropolitan area, home to nearly a million Dominicans, the largest immigrant group in the teachers' schools (Nero 176). The purpose of the seminar was twofold: first, it would allow teachers to gain theoretical knowledge of second language acquisition and bilingualism, and second, they would have to connect that new knowledge to their own 
experience learning language and culture in Santo Domingo, translating their experience into culturally responsive pedagogy (Nero 179). Nero aimed to have instructors build empathy by inhabiting their students' language and culture. Using quantitative and qualitative data from various data sources, Nero found that participants in the seminar developed empathy for their students' linguistic struggles, a better understanding of what it means to learn a language, and an appreciation for the complexity of culture and cultural adaption (Nero 175).

Another study carried out by Cole, David, and Jiménez in 2016 investigated how students' identities mediated culturally responsive instruction. Using Bonny Norton's concept of investment (Norton-Peirce; Norton), Cole and colleagues conceived of identity as dynamic and asserted that students enact agency as they participate in instruction. Accordingly, teachers needed to implement CRP while cognizant of the ways students are positioned, and position themselves and others, during instruction (Cole et al. 430). In response to state policy that mandated against teachers using languages other than English in the classroom, Cole et al. conducted a collaborative translation activity and asked students to discuss how this translation process changed their understanding of the text (Cole et al. 434). These data, together with interviews with students and parents, and recorded interactions, were gathered in three schools that were demographically diverse with respect to race, ethnicity, and language. Findings show that students' investment in collaborative translation changed over time, across settings, and also during single interactions. Further, the authors show how students contested the way the school and the researchers themselves positioned them while they negotiated their participation in the intervention (Cole et al. 440). The authors stress that the students' positioning negotiation showed their "awareness of societal discourses of position and power" (Cole et al. 440). These findings demonstrate the need for flexible pedagogy and raise awareness of the factors that can 
greatly impact the effectiveness of CRP: the challenges of acknowledging and honoring students' changing language identities and the agency used to negotiate these identities. Lastly, the authors advocate for CRP to encourage student investment, even when the investment repositions the student, teacher, and instructional approach in unexpected ways.

\section{Example of Implementation of Critical Discourse Analysis and Culturally Responsive Pedagogy in the Foreign Language Classroom}

\section{Method}

For this paper, I used autoethnography (Ellis et al.), an approach to research that seeks to describe and systematically analyze personal experience with the purpose of understanding cultural experience (1). Autoethnography allows the researcher to construct knowledge by means of critical reflection on their practice, using writing as the form of inquiry (Richardson and Adams St. Pierre). As Blair reflects, the experiences and stories shared through an autoethnography can serve as cautionary tales or as a way to inspire other educators (Blair 102).

As part of my $\mathrm{PhD}$ program, I had to conduct a teaching practicum, and my teaching was informed by research on Culturally Relevant Pedagogy (Paris; Ladson-Billings, "Toward a Theory of Culturally Relevant Pedagogy"; Gay) and Critical Discourse Analysis (van Dijk, Racism and Discourse in Latin America; van Dijk, Racism and Discourse in Spain and Latin America; van Dijk, “Aims of Critical Discourse Analysis”; van Dijk, "Principles of Critical Discourse Analysis"; Machin and Mayr; Rogers).

Because I had to document my teaching practicum, I took notes on specific ways in which I was incorporating CRP and CDA, and how students reacted to these interventions. Later, using this information, I made specific connections between the effects of these two approaches, $\mathrm{CRP}$ and $\mathrm{CDA}$, and the most important teaching and learning outcomes from the practicum. This 
autoethnography and reflection focuses on my experience as an instructor: my implementation of different activities, and my perception and analysis of student reactions to these activities.

\section{Positionality Statement}

I am a Chilean woman, raised in a middle-class family in Santiago, Chile. I belong to the first generation in my family to obtain a university degree and I am the first one to pursue graduate studies. After obtaining my BA in English Language and Linguistics in 2006, I worked for almost a decade in Chile teaching ESL (English as a Second Language) and ESP (English for Specific Purposes) in different institutions and settings. In 2013, I was accepted to begin my MA at a renowned institution in the U.S. through a local scholarship from my country. A couple of years later, I began my $\mathrm{PhD}$ in Education.

Before coming to the U.S., I was able to take part in several educational projects in Chile that enabled me to get a glimpse of the systemic educational inequities that stemmed primarily from the neoliberal agenda imposed during the Pinochet dictatorship. My participation in these projects made me aware of the injustices and complex sociohistorical contexts of the students involved, and I realized that understanding the social and political structures of power that create educational inequities is essential if we, as educators, want to be part of breaking these patterns of injustices. I've been motivated by this realization ever since, and during my $\mathrm{PhD}$ studies I began exploring these issues and learning about the similarities and differences between my country and the U.S.

\section{Data}

The data used for this study was gathered from my teaching practicum, where I taught two sections of an Advanced Grammar and Composition Course at the University of Pittsburgh. The university's student population is 66\% White, 9\% Asian, 5\% Black, 4\% Hispanic or Latino, 
and 3\% other races (Deloitte). The demographics in the classes that I taught mirrored these proportions.

During the spring semester of 2017, I taught three 50-minute classes per week, for a total of 43 classes. The Advanced Grammar and Composition Course was a high-level language course (fifth or sixth semester) with a strong emphasis on writing; its principal aim was developing students' oral and written skills in order to prepare them for content courses in Spanish. The course used as its main curricular material Taller de Escritores, a six-unit higher-level Spanish textbook (Bleichmar and Cañón). I was in charge of planning lessons, developing one of the three exams, and managing materials and activities in the two online platforms used in the course. My classes had 21 and 19 students, respectively.

This course was generally a challenging one, mostly due to the heavy workload: students had to write six online journals, three three-stage compositions, two exams, homework assignments for each of the six lessons, and a final academic essay. The course used a textbook that developed its different units around types of essays and the corresponding grammatical and lexical structures needed to create those essays.

\section{Implementation and main findings}

In this section, I will examine two factors that became very important in my teaching: a) aspects of general classroom culture that were implemented throughout the semester in both sections; and, b) the use of a CDA approach to grammar instruction. 


\section{Classroom culture}

Getting to know each other. Ladson-Billings explains that thinking about students is central to successful teaching, but the issue is how we do this. It is important to dismantle preconceived notions that we have about students, put aside our prejudices, and be conscious of our biases. Milner cautions teachers against relying too much on other people's knowledge of students instead of listening directly to them (Milner 70). For me to be able to listen to students, I felt I first needed to create an environment conducive to sharing. I needed students to feel comfortable and safe in my classroom, and they needed to know that their thoughts and ideas were going to be listened to and respected by all members of the class. Thus, I decided to start the first class by introducing myself and telling them about my journey as a language learner. When I introduced myself, I used just my first name as my preferred address. I explained, however, that I was open to other forms they might know, such as "Señorita" (Miss) or "Señora" (Mrs.) or "Profe" (colloquial, short form for "teacher"). The purpose of this introduction was to create rapport with students, but also to remind them that even though I was in a position of power, I was also just a person.

Next, I asked students to introduce themselves and tell the class their preferred name. I had learned from previous experiences that students sometimes do not like being called by their given name, they are even sometimes ashamed of it, so I knew better than to make my own assumptions, and I listened. Looking back and contemplating these introductions, I think that because reflection on language use and how we create our realities through language is an essential part of language instruction, I should have also asked students what pronouns they preferred to use; this is particularly important in Spanish and other languages where pronouns 
and other structures reflect gender. We should be cognizant of how students want to create their identities and position themselves in the target language. These gestures can lead to very interesting conversations on, for instance, how feminist movements in South America have started promoting the choice of the gender neutral form when using plural adjectives and nouns, rather than following the grammatical rule requiring the masculine form for plural constructions (Martin and Schmidt).

\section{Nurturing students' agency in the classroom.}

I wanted to nurture students' agency in their language-learning processes and make our class a co-constructed event. I enacted this in the classroom in different ways. During the first session, we reviewed the syllabus and I told them that, even though certain activities were compulsory because they were part of the curricula for all sections of the course, there were some aspects of the activities and evaluations that they could choose from. For example, students had to write a weekly entry in their blogs, and at the beginning of the semester we voted on some of the topics. We also discussed whether they agreed with the way they were being evaluated and whether the expectations for the assignment were clear for everybody. It is important to note that, even when certain aspects of the curriculum cannot be modified because of departmental rules, teachers should always ask students for feedback because there is always something that can be improved, even within constraints. Providing occasions for students to have a say in how they are evaluated or the topics they have to discuss enables them to become part of the instruction of the course and feel invested in their learning.

This agency in the classroom was not only nurtured through the choices students made concerning class activities and evaluations, but also when critically examining class materials such as the textbook, following Ladson-Billings' concept of deconstructing the curriculum. This 
was a difficult idea to present to students, because they tend to rely on the security blanket that the textbook, and sometimes dictionaries, represent when faced with the ambiguity and complexity of language. I decided to take the lead, however, and every time I departed from the textbook, I provided an explanation and opened the floor for students to express concerns and doubts on the topic. This reinforced the notion that language is constantly changing, reflecting changes in society, and that more than focusing on "right" or "wrong" constructions and sentences, we should focus on the linguistic choices we make and how these affect the meanings we create in particular circumstances.

I also made it clear to students that I welcomed a critical position towards my teaching. I encouraged them not to take for granted what I was telling them, and provided praise and encouragement when students pointed out inconsistencies in my teaching, which, of course, I tried to minimize. As teachers, we usually avoid being in vulnerable positions, especially when it comes to our knowledge, and we sometimes rationalize that if students start challenging some aspects of our knowledge, they will not be able to trust and/or respect us later (Milner). I believe, however, that there are plenty of opportunities to show respect for and earn respect from students. So, if students bring up possible corrections or alternative views in the class, it is important not to disregard them; on the contrary, they should be embraced. In my experience, students reacted positively when receiving credit for participating in the co-construction of knowledge in the classroom. One example of this was when some students provided alternatives to the examples we were using to reflect different registers and regional varieties of the language they had been exposed to. This exposure can come from the varied sociocultural contexts of their former teachers, their interests, their heritage, or other sources. As their current teachers, we tend 
to favor certain forms over others, but we should be open to learning from students and providing opportunities for students to learn from one another as well.

\section{Grammar at the service of meaning}

As I mentioned previously, the class had several different assignments that were part of the core curriculum for this course across all sections. Since I could not stray too far from the syllabus, I decided to modify my approach to presenting the materials and add culturally relevant texts (i.e., excerpts from academic articles, news articles, videos) in order to enhance our main topics of discussion. Given that the focus of the class was on developing academic writing, all lessons started with a reading, followed by comprehension questions and then analytical questions based on the main ideas of the text. These questions were usually superficial, however, and did not encourage a critical analysis. The rest of the lesson was devoted to the core activities, essentially a review of the lexical and grammatical items present in the text.

I approached the latter activities by trying to maintain the central idea presented in each unit (e.g., reviewing present continuous and sensorial perception adjectives through SFL-informed criteria). For instance, one of the units revolved around the use of passive constructions. I remembered some CDA articles I had read on racism in Latin America, and how several of them pointed to using the passive voice as a strategic move (Bisbe; van Dijk, Racism and Discourse in Spain and Latin America). To illustrate, one of the articles pointed to history textbooks using the passive voice to avoid assigning blame to those involved in the slave trade in Latin America. Textbooks stated that slaves were taken from one place to another or that they were traded. Based on this example, I collected a few such excerpts from the articles and included ideas that were expressed using the active and the passive voice. Then I asked students 
to identify the structures in the sentences and explain how they were assembled, i.e., which grammatical components were needed to form the active and the passive voice.

Later, drawing from CDA approaches, I asked the students to think critically about the meanings created by using passive sentences, and the repercussions of those meanings for the construction of, in this case, historical information. By doing this, we were actively working beyond the passive voice structure and using grammar as a meaning-making structure. Engaging students in these reflections on language use, we can also make connections to current sociopolitical events such as the Black Lives Matter movement and begin conversations on issues such as systemic racism and racist violence, and their impact on the lives of marginalized members of their own communities. It is true that these are difficult topics, especially when you have a majority of white students in the classroom, but I realized it is important to open up the discussion progressively. I believe that in order to overcome systemic oppression and injustices, we need to empower the oppressed and underserved, but we also need to provide instances of awareness for those who have never been exposed to these injustices, the privileged and the powerful.

By teaching grammar from a more critical perspective, rooted in meaning-making choices rather than in rules of usage, students explored their options more consciously, becoming more confident users of the language. They were less afraid of being grammatically incorrect. And even though my implementation of CDA in the classroom did not include instruction of specific CDA strategies to systematically analyze texts like some studies have done (e.g., Marsh; Pascual), I think it was a positive first step that allowed me to see the potential of this approach. 


\section{Conclusions and discussion}

In this article I presented the key aspects of two compatible approaches, CDA and CRP, and how they can be implemented in the foreign classroom. I also included some general reflections that stemmed from an autoethnography investigating my experience teaching two Spanish courses in which I drew from CDA and CRP.

At a practical level, it is important to mention that, as explained in the implementation section, the use of a grammar informed by Systemic Functional Linguistics and Critical Discourse Analysis methods can assist teachers in applying Culturally Relevant Pedagogy in their classes, analyzing and reflecting on the grammatical features of the language taught.

The aspects I included in the section on implementation of CDA and CRP, and all that I included in my teaching that semester, definitely fall short of the potential of these theories and approaches. Implementation has to start somewhere, however, and one experience can be instructive. In fact, this experience taught me that cultural responsiveness should not be reserved for the classroom. For those who serve both as teachers and researchers in the field, we should also be critically analyzing our research and scholarly practices. As teachers/researchers we should ask ourselves whether, and how, our pedagogies or scholarship are in any way supporting or helping perpetuate the unjust, racist, marginalizing, hegemonic practices we mean to eradicate. For example, Rosa calls for critical analysis of and reflection on how we are defining academic literacies, how we have conceptualized learning, and what and whose ways of learning and whose literacies we are asking our students to mirror and aspire to (Margarita and Rosa). He also urges and invites educators to reflect on the terminology we use for our practices, our students, and even the disciplines with which we are affiliated. For instance, in the case of Spanish in the U.S., why is it usually referred to as a foreign language, when Spanish is used by a 
considerable part of the population and has played a vital role in U.S. history? Terms such as Hispanic, Latino/a, and Latinx we sometimes take for granted. Administrators and professors have used them to name, for example, academic departments and educational programs. We have to stop and ask ourselves whose realities we are representing when using these terms, and whether these representations are fighting or perpetuating histories of oppression and racism. Concerning the research that has been done in the field of CRP and foreign language education, there are several articles that simplify CRP in foreign language education, in most cases taking out the important sociopolitical consciousness component (Ladson-Billings).

Several proponents of what Paris and Alim call asset pedagogies have described the different components such pedagogical practices entail. If we omit certain components because of their difficulty in implementation, however, we are stripping away their essence and undermining the reasons for their inclusion in the first place. Understanding these complexities is tied to understanding the complexity and fluidity of culture. Ladson-Billings warns us that we should not stay stuck in limited and superficial notions of culture (Ladson-Billings, "Culturally Relevant Pedagogy 2.0" 77). She also refers to this lack of implementation of the sociopolitical dimension, the minimizing or omitting of its critical edge even when demonstrating a more comprehensive understanding of culture. She explains that teachers should push their students to think critically about how, for example, certain policies and practices have an impact on their lives and their communities. I can apply this to ESL learners, for example, discussing the effect of recent travel bans on international students, or the effect of travel and visa restrictions due to the COVID-19 pandemic on international students and local students with family abroad.

Finally, CDA and CRP offer rich theories and approaches for language educators looking to contest static, narrow, and prejudiced notions of knowledge and culture. To this end, the 
models involve learning about the socio-historical and political backgrounds of students and their communities and, most importantly, they encourage educators and provide resources to create spaces and opportunities for students to develop and enact their own critical perspectives on the societies in which they live.

\section{Works Cited}

Abbasian, Gholam Reza, and Narjes Malaee. "The Effect of Critical Discourse Analysis Instruction on Iranian EFL Learners' Reading Comprehension and Orientation.” The Journal of Applied Linguistics, vol. 8, no. 17, 2016, pp. 1-20.

Abdel-Malek, Myriam. A Genre-Based Approach to Teaching the Written Recount in Arabic: A Mixed Methods Investigation. University of Pittsburgh Press, 2017.

Achugar, Mariana, et al. "Engaging Teachers in Language Analysis: A Functional Linguistics Approach to Reflective Literacy." English Teaching: Practice and Critique, vol. 6, no. 2, 2007, pp. 8-24, doi:10.1146/annurev.anthro.30.1.109.

Aljuaythin, Wafa. "Gender Representation in EFL Textbooks in Saudi Arabia: A Critical Discourse Analysis Approach.” International Journal of Applied Linguistics and English Literature, vol. 7, no. 5, 2018, pp. 151-57, doi:10.7575/aiac.ijalel.v.7n.5p.151.

Asgharzadeh, Roghayeh. "The Effect of Teaching Critical Reading through Critical Discourse Analysis on High School EFL Learner's Reading Comprehension." Conference on Language Learning and Teaching: An Interdisciplinary Approach, no. 1, 2012.

Baker, Will. "From Cultural Awareness to Intercultural Awareness: Culture in ELT." ELT Journal, vol. 66, no. 1, 2012, pp. 62-70, doi:10.1093/elt/ccr017.

Behnam, Biook, and Yassamin Pouriran. "Classroom Discourse: Analyzing Teacher/Learner Interactions in Iranian EFL Task-Based Classrooms.” Porta Linguarum, vol. 12, 2009, pp. $117-32$.

Bisbe, Luisana. Manifestaciones Del Discurso Racista Hacia El Indígena En Los Textos Escolares Venezolanos. Universidad Central de Venezuela, 2004.

Blair, Andrea. "Becoming Culturally Responsive: Reflections from an Autoethnographic Exploration of Teaching and Learning English in Brazil." Culturally Responsive Pedagogy: Working towards Decolonization, Indigeneity and Interculturalism, edited by Fatima Pirbhai-Illich et al., Palgrave Macmillan, 2017, pp. 99-119, doi:10.1007/978-3-319-46328-5.

Bleichmar, Guillermo, and Paula Cañón. Taller de Escritores. Grammar and Composition for Advanced Spanish. 2nd ed., Vista Higher Learning, 2016. 
Bonnah, Theodore, and Mark Donnellan. "Daily Tweet Structure and Discourse: Mixed-Method Analysis of Twitter Writing Assignments in the EFL Classroom.” INTED2017 Proceedings, vol. 1, March, 2017, pp. 3667-75, doi:10.21125/inted.2017.0899.

Bori, Pau, and Jelena Petanović. "The Representation of Immigrant Characters in Catalan as a Second Language Textbooks: A Critical Discourse Analysis Perspective.” Lengua y Migracion, vol. 9, no. 2, 2017, pp. 61-75.

Brice-Heath, Shirley. Ways with Words: Language, Life, and Work in Communities and Classrooms. Cambridge UP, 1983, doi:10.1136/bmj.311.7013.1154.

Canale, Germán. "( $\mathrm{Re})$ Searching Culture in Foreign Language Textbooks, or the Politics of Hide and Seek." Language, Culture and Curriculum, vol. 29, no. 2, Taylor \& Francis, 2016, pp. 225-43, doi:10.1080/07908318.2016.1144764.

Cárdenas, María Luisa, and José Francisco Rivera. "El Análisis Del Discurso En El Aula: Una Herramienta Para La Reflexión.” Educere, vol. 10, no. 32, 2006, pp. 43-48.

Cazden, Courtney, and Ellen Legget. Culturally Responsive Education: A Discussion of LAU Remedies II. Prepared for the U.S. Department of Health, Education, and Welfare. 1976.

Chen, Dianbing, and Xinxiao Yang. "Improving Active Classroom Participation of ESL Students: Applying Culturally Responsive Teaching Strategies." Theory and Practice in Language Studies, vol. 7, no. 1, 2017, pp. 79-86, doi:10.17507/tpls.0701.10.

Chen, Guo-Ming, and William J. Starosta. "A Review of the Concept of Intercultural Awareness." Human Communication, vol. 2, 1998, pp. 27-54, doi:10.1002/ejoc.201200111.

Clark, Romy, and Roz Ivanic. "Critical Discourse Analysis and Educational Change." Encyclopedia of Language and Education, edited by L. van Lier and D. Corson, Kluwer Academic Publishers, 1997, pp. 217-27.

Cole, Mikel, et al. "Collaborative Translation: Negotiating Student Investment in Culturally Responsive Pedagogy.” Language Arts, vol. 93, no. 6, 2016, pp. 430-43.

Dar, Zeinab Koupaee, et al. "Teaching Reading with a Critical Attitude: Using Critical Discourse Analysis (CDA) to Raise EFL University Students' Critical Language Awareness (CLA).” International Journal of Criminology and Sociological Theory, vol. 3, no. 2, 2010, pp. 457-76.

Deloitte. "DATA USA: University of Pittsburgh-Pittsburgh Campus." DATA USA, 2020, https://datausa.io/profile/university/university-of-pittsburgh-pittsburgh-campus\#: :text=1\% 2C397-. Accessed 3 Aug. 2020.

Dost, Güliz Turgut. "Preparing Linguistically Responsive Teachers through Experiential Foreign Language Tasks: A Phenomenological Study." Cogent Education, vol. 3, Cogent, 2016, pp. 1-20, doi:10.1080/2331186X.2016.1169614.

Ducar, Cynthia Marie. (Re) Presentations of U. S . Latinos : A Critical Discourse Analysis of Spanish Heritage Language Textbooks in the Graduate College. University of Arizona, 
2006.

Ellis, Carolyn, et al. “Autoethnography: An Overview.” Qualitative Social Research, vol. 12, no. 1, 2011, pp. 1-14, http://www.qualitative-research.net/index.php/fqs/article/view/1589/3095. Accessed 3 Aug. 2020.

Fairclough, Norman. Critical Language Awareness. Harlow, 1992.

---. Discourse and Social Change. Polity Press, 1992.

Fairclough, Norman, and Ruth Wodak. "Critical Discourse Analysis." Discourse Studies: A Multidisciplinary Introduction, edited by Teun A. Van Dijk, Sage Publications, 1997, pp. 258-84.

Fang, Zhihui, and Mary J. Schleppegrell. "Disciplinary Literacies Across Content Areas: Supporting Secondary Reading Through Functional Language Analysis.” Journal of Adolescent \& Adult Literacy, vol. 53, April 2010, pp. 565-74, doi:10.1598/JA.

Fernández, Loretta. Learning Another Language with Conceptual Tools: An Investigation of Gal'Perin's Concept-Oriented Instruction. University of Pittsburgh, 2017.

Fernández Martínez, Dolores. "Critical Learning: Critical Discourse Analysis in EFL Teaching." Journal of Language Teaching and Research, vol. 3, no. 2, 2012, pp. 283-88, doi:10.4304/jltr.3.2.283-288.

Freire, Paulo. Pedagogy of the Oppressed. Bloomsbury, 1970.

Gay, Geneva. Culturally Responsive Teaching: Theory, Research, and Practice. 2nd ed., Teachers College Press, 2010.

Giroux, Henry. Border Crossings: Cultural Workers and the Politics of Education. Routledge, 1992.

Giroux, Henry, and Peter McLaren, editors. Critical Pedagogy, the State, and Cultural Struggle. State University of New York Press, 1989.

Glas, Katharina. "El Inglés Abre Puertas ... ¿a Qué? Análisis Del Discurso Sobre La Enseñanza Del Inglés En Chile, 2003-2006." Revista Educación y Pedagogía, vol. 20, no. 51, 2008, pp. 111-22.

Gómez Lobatón, July Carolina. "Language Learners' Identities in EFL Settings: Resistance and Power through Discourse." Colombian Applied Linguistics Journal, vol. 14, no. 1, 2012, pp. 60-76, doi:10.14483/22487085.3813.

Guerrero, Carmen Helena. "The Portrayal of EFL Teachers in Official Discourse: The Perpetuation of Disdain.” Profile, vol. 12, no. 2, 2010, pp. 33-49.

Habli, Farah Omar. "Culturally Responsive Teaching and Bilingual Students' Literacy Skills in the Middle East.” Arab World English Journal, vol. 6, no. 3, 2015, pp. 357-66. 
Halliday, Michael A. K., and Christian M. I. M. Matthiessen. Halliday's Introduction to Functional Grammar. 4th ed., Routledge, 2014.

Hashemi, Mohammad Raza, and Afsaneh Ghanizadeh. "Critical Discourse Analysis and Critical Thinking: An Experimental Study in an EFL Context." System, vol. 40, no. 1, Elsevier Ltd., 2012, pp. 37-47, doi:10.1016/j.system.2012.01.009.

Hazaea, Abduljalil Nasr. "Fostering Critical Intercultural Awareness among EFL Students through Critical Discourse Analysis." Ikala, Revista de Lenguage y Cultura, vol. 25, no. 1, 2020, pp. 17-33, doi:10.17533/udea.ikala.v25n01a06.

Hesar, Mohammad Pourmahmoud, et al. "Why and How to Apply Culture in an EFL Classroom?" International Conference on Language, Media and Culture, vol. 33, 2012, pp. $68-72$.

hooks, bell. Teaching to Transgress. Routledge, 1994.

Jacob, Evelyn, and Cathie Jordan. "Moving to Dialogue." Anthropology \& Education Quarterly, vol. 18, no. 1, 1987, pp. 256-61.

Kern, Richard. "Making Connections through Texts in Language Teaching." Language Teaching, vol. 41, no. 3, 2008, pp. 367-87, doi:10.1017/S0261444808005053.

Khanshan, Shabnam Kurosh, and Davud Kuhi. "The Contribution of Critical Discourse Analysis and Critical Thinking in an EFL Context: A Case Study of Economic Texts." Journal of Modern Research in English Language Studies, vol. 4, no. 3, 2017, pp. 33-47, http://www.albayan.ae.

Kim, Jun Sook. Rethinking Discourse of Diversity: A Critical Discourse Study of Language Ideologies and Identity Negotiation in a University ESL Classroom. The Ohio State University, 2017.

Kissau, Scott, et al. "Motivation, Race, and Foreign Language Instruction: The Need for Culturally Responsive Teaching." The NECTFL Review, September 2011, pp. 39-61.

Kramsch, Claire. "Teaching Language along the Cultural Faultline." Context and Culture in Language Teaching, Oxford UP, 1996, pp. 205-32.

---. “The Symbolic Dimensions of the Intercultural.” Language Teaching, vol. 44, no. 3, 2011, pp. 354-67, doi:10.1017/S0261444810000431.

Kress, Gunther. Linguistic Processes in Sociocultural Practice. Deakin University Press, 1985.

Kuiper, Ruthanne. "Enhancing Metacognition through the Reflective Use of Self-Regulated Learning Strategies.” The Journal of Continuing Education in Nursing, vol. 33, no. 2, 2002, pp. $78-87$.

Labov, William. Language in the Inner City. University of Pennsylvania Press, 1972.

Ladson-Billings, Gloria. "But That's Just Good Teaching! The Case for Culturally Relevant Pedagogy." Theory into Practice, vol. 34, no. 3, 2016, pp. 159-65, 
doi:10.3726/978-1-4539-1584-4/43.

---. "Culturally Relevant Pedagogy 2.0: A.k.a. the Remix." Harvard Educational Review, vol. 84, no. 1, 2014, pp. 74-84, doi:10.17763/haer.84.1.p2rj131485484751.

---. "From the Achievement Gap to the Education Debt: Understanding Achievement in U.S. Schools." Educational Researcher, vol. 35, no. 7, 2006, pp. 3-12, doi:10.3102/0013189X035007003.

---. The Dreamkeepers: Successful Teachers of African American Children. Second, Wiley, 2009.

---. "Toward a Theory of Culturally Relevant Pedagogy." American Educational Research Journal, vol. 32, no. 3, 1995, pp. 465-91, doi:10.3102/00028312032003465.

---. “'Yes, But How Do We Do It?' Practicing Culturally Relevant Pedagogy.” White Teachers/Diverse Classrooms, edited by J. Landsman and C. Lewis, Stylus Publishing, 2006, pp. 29-41, http://fordhamatsdc.files.wordpress.com/2011/08/ladson-billings_g-_yes_but_how_do_we_ do_it.pdf.

Leung, Doris Y. P., and David Kember. "The Relationship between Approaches to Learning and Reflection upon Practice." Educational Psychology, vol. 23, no. 1, 2003, pp. 61-71.

Liu, Yongbing. "The Construction of Cultural Values and Beliefs in Chinese Language Textbooks: A Critical Discourse Analysis." Discourse: Studies in the Cultural Politics of Education, vol. 26, no. 1, 2005, pp. 15-30, doi:10.1080/01596300500039716.

Lucas, Tamara, et al. "Linguistically Responsive Teacher Education: Preparing Classroom Teachers to Teach English Language Learners." Journal of Teacher Education, vol. 59, no. 4, 2008, pp. 361-73, doi:10.1177/0022487108322110.

Lucas, Tamara, and Ana María Villegas. "A Framework for Preparing Linguistically Responsive Teachers." Teacher Preparation for Linguistically Diverse Classrooms: A Resource for Teacher Educators, edited by Tamara Lucas, Routledge, 2011, pp. 55-72.

Luke, Carmen, and Jennifer Gore, editors. Feminisms and Critical Pedagogy. Routledge, 1992.

Machin, David, and Andrea Mayr. How To Do Critical Discourse Analysis. A Multimodal Introduction. Sage, 2012.

Marashi, Hamid, and Azam Chizari. "Using Critical Discourse Analysis Based Instruction to Improve EFL Learners' Writing Complexity, Accuracy and Fluency.” The Journal of Applied Linguistics, vol. 9, no. 19, 2016, pp. 37-61.

Margarita, Stacey, and Jonathan Rosa. "Episode 142: Language Legitimacy and Imagining New Educational Contexts with Jonathan Rosa." We Teach Languages Podcast, 2020, https://weteachlang.com/2020/06/12/142-with-jonathan-rosa/. Accessed 3 Aug. 2020.

Marsh, David. Using Critical Discourse Analysis to Raise Critical Language Awareness in Japanese Medical Students: An Exploratory Action Research Project. 2011. University of 
Birmingham, MA dissertation.

Martin, James R., and Peter R. R. White. The Language of Evaluation: Appraisal in English. 1st ed., Palgrave Macmillan, 2005, doi:10.1057/9780230511910.

Martin, Michel, and Samantha Schmidt. "A New Effort in Argentina Seeks to Make Spanish Nouns Gender Neutral." NPR World, 2019, https://www.npr.org/2019/12/08/786135746/a-new-effort-in-argentina-seeks-to-make-spanis h-nouns-gender-neutral. Accessed 3 Aug. 2020.

McIntosh, Kent, et al. "Effects of a Culturally Responsive Speech and Language Intervention for Students of Indigenous and Non-Indigenous Heritage." Canadian Journal of Education, vol. 34, no. 3, 2011, pp. 181-95.

McLaren, Peter. Life in Schools: An Introduction to Critical Pedagogy in the Foundations of Education. 2nd ed., Longman, 1994.

Mellom, Paula J., et al. “'They Come with Nothing': How Professional Development in a Culturally Responsive Pedagogy Shapes Teacher Attitudes towards Latino/a English Language Learners." Teaching and Teacher Education, vol. 71, Elsevier Ltd., 2018, pp. 98-107, doi:10.1016/j.tate.2017.12.013.

Milner, H. Richard. Rac(e)ing to Class: Confronting Poverty and Race in Schools and Classrooms. Harvard Education Press, 2015.

Moeller, Aleidine J., and Sarah R. Faltin Osborn. "A Pragmatist Perspective on Building Intercultural Communicative Competency: From Theory to Classroom Practice." Foreign Language Annals, vol. 47, no. 4, 2014, pp. 669-83, doi:10.1111/flan.12115.

Moll, Luis. "Literacy Research in Community and Classrooms: A Sociocultural Approach." Multidisciplinary Perspectives in Literacy Research, edited by R. Beach et al., National Conference on Research in English and National Council of Teachers of English, 1992, pp. $211-44$.

Moll, Luis, and Norma González. "Lessons from Research with Language-Minority Children." Journal of Literacy Research, vol. 26, no. 4, 1994, pp. 439-56, doi:10.1080/10862969409547862.

Morgan, Brian. "Modals and Memories: A Grammar Lesson on the Quebec Referendum on Sovereignty." Critical Pedagogies and Language Learning, edited by B. Norton and K. Toohey, Cambridge University Press, 2004, pp. 158-78.

Najarzadegan, Sahar, et al. “The Impact of Practicing van Dijk's Model of Critical Discourse Analysis on the Improvement of Iranian EFL Undergraduates' Critical Thinking across Different Proficiency Levels." Iranian Journal of English for Academic Purposes (IJEAP), vol. 7, no. 1, 2018, pp. 1-16.

Nero, Shondel. "Inhabiting the Other's World: Language and Cultural Immersion for US-Based Teachers in the Dominican Republic." Language, Culture and Curriculum, vol. 22, no. 3, 2009, pp. 175-94, doi:10.1080/07908310903203066. 
Nieto, Sonia. Affirming Diversity: The Sociopolitcal Context of Multicultural Education. Longman, 1992.

Norton-Peirce, Bonny. "Social Identity, Investment, and Language Learning." TESOL Quarterly, vol. 29, no. 1, 1995, pp. 9-31, doi:10.2307/3587803.

Norton-Peirce, Bonny, and Kelleen Toohey. "Critical Pedagogies and Language Learning: An Introduction." Critical Pedagogies and Language Learning, edited by Bonny Norton and Kelleen Toohey, 1st ed., Cambridge University Press, 2004, pp. 1-15, doi:10.2167/lcc019b.0.

Norton, Bonny. Identity and Language Learning. 2nd ed., Multilingual Matters, 2013.

Nzai, Valentin Ekiaka, et al. 'Non-Native English Speaking Elementary ELL Teachers' Culturally Responsive Leadership Profile in an ESL Context." Colombian Applied Linguistics Journal, vol. 14, no. 2, 2012, pp. 88-108, doi:10.14483/udistrital.jour.calj.2012.2.a06.

Paris, Django. "Culturally Sustaining Pedagogy: A Needed Change in Stance, Terminology, and Practice." Educational Researcher, vol. 41, no. 3, 2012, pp. 93-97, doi:10.3102/0013189X12441244.

Paris, Django, and H. Samy Alim. "What Are We Seeking to Sustain through Culturally Sustaining Pedagogy? A Loving Critique Forward." Harvard Educational Review, vol. 84, no. 1, 2014, pp. 85-100, doi:10.17763/haer.84.1.9821873k2ht16m77.

Pascual, Mariana. "El Empoderamiento En El Aula de Lenguas Extranjeras: Una Propuesta Desde El Análisis Crítico Del Discurso y La Teoría de La Valoración.” Lenguaje, vol. 42, no. 1, 2014, pp. 71-95, doi:10.25100/lenguaje.v42i1.4979.

Perales Escudero, Moisés Damián. "Teaching Intercultural Awareness in the English as a Foreign Language Classroom: A Case Study Using Critical Reading.” Intercultural Education, vol. 24, no. 3, 2013, pp. 251-63, https://www.tandfonline.com/doi/abs/10.1080/14675986.2013.793037.

Porto, Melina. “Culturally Responsive L2 Education : An Awareness-Raising Proposal.” ELT Journal, vol. 64, no. 1, 2010, pp. 45-53, doi:10.1093/elt/ccp021.

Richardson, Laurel, and Elizabeth Adams St. Pierre. "Writing: A Method of Inquiry." Handbook of Qualitative Research, edited by N. Denzin and Y. Lincoln, 3rd ed., SAGE, 2004.

Rogers, Rebecca, editor. An Introduction to Critical Discourse Analysis in Education. Lawrence Erlbaum Associates, 2004.

---. "Critical Discourse Analysis in Education : A Review of the Literature." Review of Educational Research, vol. 75, no. 3, 2005, pp. 365-416.

Rogers, Rebecca, and Inda Schaenen. "Critical Discourse Analysis in Literacy Education: A Review of the Literature." Reading Research Quarterly, vol. 49, no. 1, 2014, pp. 121-43, doi:10.1002/rrq.61. 
Sadeghi, Sima, et al. "Application of Critical Classroom Discourse Analysis (CCDA) in Analyzing Classroom Interaction.” English Language Teaching, vol. 5, no. 1, 2012, pp. 166-73, doi:10.5539/elt.v5n1p166.

Schleppegrell, Mary, and Mariana Achugar. "Learning Language and Learning History: A Functional Linguistics Approach.” TESOL Journal, vol. 12, no. 2, 2003, pp. 21-27.

Schleppegrell, Mary J., et al. "The Grammar of History: Enhancing Content-Based Instruction through a Functional Focus on Language." TESOL Quarterly, vol. 38, no. 1, 2004, pp. 67-93, doi:10.2307/3588259.

Setyono, Budi. "The Portrayal of Women in Nationally-Endorsed English as a Foreign Language (EFL) Textbooks for Senior High School Students in Indonesia." Sexuality and Culture, vol. 22, 2018, pp. 1077-93, doi:10.1007/s12119-018-9526-2.

Shardakova, Marya, and Aneta Pavlenko. "Identity Options in Russian Textbooks." Journal of Language, Identity \& Education, vol. 3, no. 1, 2004, pp. 25-46, doi:10.1207/s15327701jlie0301_2.

Skopinskaja, Liljana. "The Role of Culture in Foreign Language Teaching Materials: An Evaluation from an Intercultural Perspective." Incorporating Intercultural Communicative Competence in Language Teacher Education, 2003, pp. 41-68.

Smitherman, Geneva. Talkin and Testifyin. Wayne State University Press, 1977.

Sunardi, Sunardi, et al. "Experiential Realizations of Pedagogic Discourse in an Indonesian EFL Classroom." International Journal of Language Teaching and Education, vol. 2, no. 3, 2018, pp. 205-15, doi:10.2991/icems-17.2018.46.

Tan, Fujuan, et al. "International ESL Graduate Student Perceptions of Online Learning in the Context of Second Language Acquisition and Culturally Responsive Facilitation." Adult Learning, vol. 21, no. 1-2, 2010, pp. 9-14, doi:10.1177/104515951002100102.

Valdes, Francisco. "Forward: Latina/o Ethnicities, Critical Race Theory and Post-Identity Politics in Postmodern Legal Culture: From Practices to Possibilities." La Raza Law Journal, vol. 9, 1996, pp. 1-31.

van Dijk, Teun A. “Aims of Critical Discourse Analysis.” Japenese Discourse, vol. 1, no. 1, 1995, pp. 17-27, doi:10.1177/0957926593004002006.

---. Ideology. SAGE, 1998.

---. "Principles of Critical Discourse Analysis." Discourse \& Society, vol. 4, no. 2, 1993, pp. 249-83.

---, editor. Racism and Discourse in Latin America. Lexington Books, 2009.

---, editor. Racism and Discourse in Spain and Latin America. John Benjamins Publishing Company, 2005.

Wallace, Catherine. "Critical Language Awareness: Key Principles for a Course in Critical 
Reading." Language Awareness, vol. 8, no. 2, 1999, pp. 98-110, https://www.tandfonline.com/doi/abs/10.1080/09658419908667121.

---. Critical Reading in Language Education. Routledge, 2003.

Watson, Goodwin, and Edwin Glaser. Watson-Glaser Critical Thinking Appraisal. The Psychological Corporation, 2002.

Węgrzecka-Kowalewski, Eva. Critical Thinking in Intensive Language Programs for International Students in U.S. Universities. University of Pittsburgh, 2018, http://d-scholarship.pitt.edu/35367/1/8.16 ETD Dissertation Eva Węgrzecka-Kowalewski FINAL \%281\%29.pdf. Accessed 3 Aug. 2020.

Weninger, Csilla, and Tamas Kiss. "Culture in English as a Foreign Language (EFL) Textbooks: A Semiotic Approach.” TESOL Quarterly, vol. 47, no. 4, 2013, pp. 694-716, doi: $10.1002 /$ tesq. 87.

Wharton, Sue. "Critical Text Analysis: Linking Language and Cultural Studies." ELT Journal, vol. 65, no. 3, 2011, pp. 221-29, doi:10.1093/elt/ccq068.

Wodak, Ruth, and Michael Meyer. "Critical Discourse Analysis: History, Agenda, Theory, and Methodology." Methods of Critical Discourse Analysis, edited by Ruth Wodak and Michael Meyer, 2nd ed., SAGE, 2009, pp. 1-33, doi:10.1016/S0376-7361(09)70018-4.

---, editors. Methods of Critical Discourse Analysis. 1st ed., SAGE, 2001.

Xin, Liu, et al. "EFL (English as a Foreign Language) Classroom Discourse Analysis of a Vocational College and Some Reflections." US-China Education Review B, vol. 6, 2011, pp. $752-55$.

Xiong, Tao. "Essence or Practice? Conflicting Cultural Values in Chinese EFL Textbooks: A Discourse Approach." Discourse: Studies in the Cultural Politics of Education, vol. 33, no. 4, 2012, pp. 499-516, doi:10.1080/01596306.2012.692958.

---. "Shallow Environmentalism: A Preliminary Eco-Critical Discourse Analysis of Secondary School English as a Foreign Language (EFL) Texts in China." The Journal of Environmental Education, vol. 45, no. 4, 2014, pp. 232-42, doi:10.1080/00958964.2014.943686.

Xiong, Tao, and Yamin Qian. "Ideologies of English in a Chinese High School EFL Textbook: A Critical Discourse Analysis." Asia Pacific Journal of Education, vol. 32, no. 1, 2012, pp. 75-92, doi:10.1080/02188791.2012.655239.

Xiong, Tao, and Zhou min Yuan. "“It Was Because I Could Speak English That I Got the Job': Neoliberal Discourse in a Chinese English Textbook Series." Journal of Language, Identity and Education, no. 2, Routledge, 2018, pp. 103-17, doi:10.1080/15348458.2017.1407655.

Yoshida, Hiroko. "An Analysis of Discourse in the EFL Classroom." Osaka Keidai Ronshu, vol. 59 , no. 2, 2008, pp. 1-14. 
Zhang, Rong, and Dale Steele. "Improving Intercultural Awareness: A Challenging Task for Japan." The Procedia - Social and Behavioral Sciences, vol. 47, Elsevier B.V., 2012, pp. 52-63, doi:10.1016/j.sbspro.2012.06.613. 